\section{Intersections}

Canadian Journal of Music

Revue canadienne de musique
Intersections CANADIAN JOURAL OF MUSIO

\title{
The Message of the Carillon: Bells as Instruments of Colonialism in Twentieth-Century Canada
}

\section{Patrick Nickleson}

Volume 36, numéro 2, 2016

URI : https://id.erudit.org/iderudit/1051594ar

DOI : https://doi.org/10.7202/1051594ar

Aller au sommaire du numéro

\section{Éditeur(s)}

Canadian University Music Society / Société de musique des universités canadiennes

\section{ISSN}

1911-0146 (imprimé)

1918-512X (numérique)

Découvrir la revue

Citer cet article

Nickleson, P. (2016). The Message of the Carillon: Bells as Instruments of Colonialism in Twentieth-Century Canada. Intersections, 36(2), 13-25.

https://doi.org/10.7202/1051594ar

\section{Résumé de l'article}

Les cloches et les carillons ont longtemps symbolisé l'harmonie de la communauté dans les discours politiques euro-américains. Cet article cherche à déconstruire cette posture rhétorique en reconsidérant les cloches et les carillons dans le contexte du Canada de l'entre-deux-guerres. Dans un premier temps, on y analyse le discours d'inauguration du carillon de la Colline Parlementaire de William Lyon Mackenzie King à travers le prisme d'une nostalgie canadienne coloniale propre à l'« ancien monde " pour le carillon. On analyse ensuite les témoignages de survivants du système canadien d'internats pour montrer que le lien entre les cloches, l'harmonie et la communauté a été fortement imposé par les colons afin d'éliminer à la source toute discorde potentielle.
Copyright @ Canadian University Music Society / Société de musique des universités canadiennes, 2018
Ce document est protégé par la loi sur le droit d'auteur. L'utilisation des services d'Érudit (y compris la reproduction) est assujettie à sa politique d'utilisation que vous pouvez consulter en ligne.

https://apropos.erudit.org/fr/usagers/politique-dutilisation/ 


\title{
THE MESSAGE OF THE CARILLON: BELLS AS INSTRUMENTS OF COLONIALISM IN TWENTIETH-CENTURY CANADA
}

\author{
Patrick Nickleson ${ }^{1}$
}

On 1 July 1927, Canadian Prime Minister William Lyon Mackenzie King stood on Parliament Hill in Ottawa and inaugurated the Peace Tower carillon. His address on the Diamond Jubilee of Canadian Confederation (1928, 3-13), turns on two rhetorical tropes that have long been noted in the campanological literature. First of all, like many in the new world, the Peace Tower was built as a memorial to lives lost in the First World War, thus functioning as what Tiffany $\mathrm{Ng}$, among others, labels a "peace carillon" (2015, 128-40). And second, the speech drew on the long oratorical tradition in which, as Alain Corbin writes, "the harmony of the bells seemed to guarantee that of the community" (1998, 79).

As much as Mackenzie King's speech fits within this rhetorical tradition, in this article I want to argue that the context into which it was delivered was markedly different from that typically understood in campanological literature focused on Europe in the sixteenth through twentieth centuries. In general, because the carillon was a relatively new instrument for any Canada-born settler to that point, and in particular because the carillon was imported as one among many symbols of a unity that was being colonially imposed through genocidal practices imposed upon Canada's Indigenous populations. Bells played a major role in these developments through their knotting of colonial, sonic, and musical practices. As such, I want to highlight the political context within which Canada's first carillons were planned and constructed, alongside the very different way that individual signal bells were heard among Indigenous children in the genocidal Indian residential school system. While individual signal bells to mark time-of obligations, observances, festivities, work, and so on-differ markedly from the instrument of the carillon, I elide the two in my treatment in a way that goes against the careful specificity of

1 This article was first presented at and gained greatly from "Resonance and Remembrance: An Interdisciplinary Campanology Symposium," organized by Tiffany Ng and hosted at the University of Michigan in the spring of 2017 and then at the 2017 MusCan meeting. Many thanks are owed to the anonymous peer reviewer from Intersections who captured many novice errors in my application of technical terminology related to bells and pushed me to clarify the broader political arguments at its core. It is stronger for their efforts. 
recent developments in campanological research. ${ }^{2}$ The two are markedly different, not only in their function but even in their design and casting, but my particular interest is in the role of bells as symbols of harmonious community, and thus specifically of listening to and talking about bells. My focus is the political and oratorical place of bells in twentieth-century Canada and the clear disjunction between settler and Indigenous methods of hearing them.

The prominent and seemingly paradoxical role that dissonant hearings, dispute, and disagreement have played in the literature on bells is part of what first drew me to this topic. Indeed, even dissatisfaction and dismissal are constitutive of writing on the instrument from its earliest appearances in English-language literature. Writing from Amsterdam in 1772, Charles Burney called a performance by the carillonneur Jacob Potholt "a drudgery unworthy of his genius." Burney was clearly irritated at having to watch Potholt, whose playing on the Olde Kerk organ had dazzled Burney hours earlier, performing on the Amsterdam Stad-huys carillon. Burney felt that the "barbarous invention" would be just as appreciated by its ignorant audience if it was played by "some hewer of wood, [or] drawer of water" and was thus well below the great organist's station and skill. Had their taste not failed them, Burney continues, the people of Amsterdam could have easily afforded one of the best bands in Europe for the cost of the tower's programmable cylinder and bells-"but those who can be charmed with barrel music certainly neither want nor deserve better" (284-98). For Burney, the carillon is an instrument of bemusement and perhaps even disdain. While he admires the music Potholt can draw from it, he clearly considers the instrument barbarous and is even more convinced that the audience for it does not appreciate the skill of its performer. Both the instrument and its audience are disagreeable for Burney, despite the evident skill of its performer.

Moments like these continue through campanological literature. In his landmark study of bells in nineteenth-century French villages, Alain Corbin highlights moments of dispute over bells: their placement, their tuning and construction, the terse negotiations between a founder and his potential clients that might lead to a contractual "agreement" $(1998,82)$, the disputes over valuable bronze between communes and the new Republican government, and even "uproar[s]" over incomplete baptism ceremonies leading to the failed consecration of "bastard bells" (90). Similarly, University of Michigan carillonneur and carillon scholar Tiffany $\mathrm{Ng}$ has shown the ways in which the harmonious gift of a carillon from the Netherlands to the United States after the Second World War led to musical, political, diplomatic, and social discord (2015, 119-68). In his history of the "Noisy Renaissance," Niall Atkinson focuses on the dissonant social relations produced by bells within the "two poles" of

2 I am thinking here in particular of Luc Rombouts's Singing Bronze: A History of Carillon Music (2014), as well as Tiffany Ng's dissertation (2015). Moreover, it is clear that the recent symposium on bell music organized by Ng at the University of Michigan, and the creation of the Journal of Campanology seek to escape the very elisions between different practices of bell production and performance that I rely on here. 
the Florentine Renaissance soundscape: "the will to a universal harmony and the dissonant networks of verbal disorder" (2016, 49-54).

It seems, then, that the motivating paradox of campanological research has been the disharmony internal to bells: the very clear disjunction between the rhetoric of the bell ringing the "harmonious" community and its role as an antidote to the disorder that has supposedly plagued democracy at least since Plato, as outlined by the philosopher Jacques Rancière $(2006,30)$. For Atkinson, this can be summarized as the discord between the harmony of the bells and the noise of the crowd; for Corbin, it is allegorized as the dispute of the bronze with itself, as it becomes the equivalent resource in the production of both bell of peace and munition of war; for $\mathrm{Ng}$, it is the discord between the carillon as both symbol of peace and instrument of cold war containment rhetoric. More generally, Burney's (at best) ambivalent response to the instrument and its audience transports us back to a first encounter with the carillon in which it had not yet gained its "power to evoke a universalized Old World heritage" $(\mathrm{Ng} 2015,119)$ - a preconditioned encounter to be kept in mind in the Canadian context.

These are oversimplifications of these texts, but my point is that denaturalizing the political trope of the harmonious bells seems to be a core mission of campanological research in the last two decades. Nevertheless, I aim to differ slightly from each of them. In the above literature, the sound of the carillon, and most importantly the bells as symbols - to either agree or disagree withpervades not only the soundscape historicized but also the historiography itself. That is to say, in all the literature, bells always ring within a community that hear them within a culture in agreement about the role of bells-the disagreements and disputes are nuanced ones over management and best practices in a community saturated by bells. Shifting to Canada in the immediate aftermath of the First World War, Mackenzie King's rhetorical reliance on the bells must not be understood as a convenient metaphor for political harmony, as it perhaps had in the Europe covered by Corbin and Atkinson, but rather as one element within a larger, violent imposition of colonial order. I thus want to follow Ng in "developing our awareness of the carillon's historical role in ... colonialism," towards an awareness of a world where the bells' "utopian intentions [are] ill received" ( $\mathrm{Ng} 2015,121)$. Canada is a nation of internal colonization, and our carillons need to be understood this way-particularly as a majority of them were built as war memorials during the 1920s, as imposed, sounding claims of unity with an Old World heritage recently experienced by many soldiers. I will consider the relationship between, on the one hand, what we can call-against all convention-Mackenzie King's utopian manifesto on Canada Day 1927, and on the other, a handful of testimonial commentaries on single signal bells from First Nations survivors of the Canadian Indian residential school system. Unlike in most campanological literature, the bells were not noisy in being cracked, miscast, misplaced, incorrectly baptized "bastard bells," or rung by the wrong group for the wrong occasion. It had nothing to do with bells speaking their language poorly. Rather, for these children, the very sound and function of bells was a colonial imposition of foreign clock time and 
an element of an unwelcome order that, for European settlers, erroneously still goes by the shared sonic and political name "harmony."

Canada's relationship to the British Crown was at the forefront of Mackenzie King's speech at the opening of the Peace Tower carillon in 1927. Noting that the carillon had been designed to reproduce Big Ben and the Westminster Chimes, King proclaims, "When, therefore, from time to time, we hear the striking of the hours and the quarters, we shall be reminded of the heritage of freedom which has come to us through the establishment in Canada of British parliamentary institutions ... [which is] the surest bond of union between the community of free nations which comprise the British Commonwealth" (Mackenzie King 1928, 9). It was within this effort to reproduce and resonate with the bells of Westminster that the largest bell is inscribed:

This carillon was installed

By the authority of Parliament

To commemorate

The Peace of 1918

And

To keep in remembrance

The service and sacrifice

Of Canada

In the Great War

The sound bow of the bell reads, "Glory to God in the Highest and on Earth Peace, Goodwill toward men." In its combination of religious, political, and musical harmony, the Peace Tower is thus an ideal rendering of Tiffany Ng's description of the carillon as symbol of peace and togetherness-a discourse that is central to its colonial imposition and function. This, Mackenzie King's continues, "is the message of the carillon - ... [it is] the voice of a nation in thanksgiving and praise" (Mackenzie King 1928, 12-13).

Another speech at Parliament focused on much the same themes, further providing a concrete unifying context to the history of the carillon in Canada. In his address delivered to the North American Congress of Carillonneurs in Ottawa in September 1936, H.M. Nornabell, director of the Mountain Lake Sanctuary and Singing Tower, addressed the gathered delegates. Reflecting on the Peace Tower's role as a memorial to the war, the veteran announces, of course unaware of another war only a few years out, "it is indeed a far cry from those days to our meeting here tonight."

During those years in Belgium and Northern France-the home of the carillon-I saw how those war-torn countries found an unbroken spirit, a will to live true to their traditions, kept alive for them-not just by the music of the bells, but by the meaning of the carillon as the voice of its people. In fact, nothing for me so epitomized this deeper meaning of a carillon than when I saw the grief of Ypres, as the beautiful Cloth Hall was shell-exploded into a mass of flames and its martyred carillon fell, a molten holocaust. (Nornabell 1936, np; my italics) 
Nornabell was unlikely the only person in the room who had spent time in Europe during the war; for each, this call to tradition, as embodied in a nostalgia for the bells of France and Belgium, serves as a reminder of the necessity of their role in bringing life to the carillon in the New World, importing not only the music of the instrument but perhaps more importantly its long-held meaning as the voice of its people: "In those war years I saw what a carillon really meant-not as a mere musical diversion or ornamental sound, but as an instrument of genuine moral suasion in the life of a community. I came to an understanding of what the carillon could and should become to the New World as it had to the Old World of the bells" (Nornabell 1936, np).

The Peace Tower carillon was not the only Canadian instrument built for and contributing to this narrative. Canada's first carillon began ringing on 2 April 1922 at Metropolitan United Church at the corner of Queen and Church in downtown Toronto. Simcoe, Ontario's, Norfolk War Memorial followed in 1925. A year later, the carillon at St. George's Church in Guelph was opened, and 1927 saw perhaps Canada's two most famous instruments, both directly tied to the nation's Diamond Jubilee and war memorialization: first, the Peace Tower in July and then the Soldier's Tower Carillon at the University of Toronto in the fall. ${ }^{3}$ Two others followed before 1940: at the Cathedral of Christ the King in Hamilton in 1933, and St-Jean-Baptiste Church in Ottawa in 1940. The remaining carillons in Canada are less relevant here; importantly, however, of the remaining four, only one is attached to a church, Montreal's Carillon of St. Joseph's Oratory (1956). The other three are more associated with tourism or diplomacy: the Niagara Fall's Rainbow Tower (1947), Toronto's Exhibition Place carillon (1974), and Victoria, British Columbia's, Netherlands Centennial Carillon (1967). In sum, of Canada's eleven carillons, nine are in Ontario; of those nine, all but one (at the Canada National Exhibition grounds) were built between 1922 and 1940 as war memorials.

Canada's only other carillon was perhaps its most widely heard but also its most short-lived. During the Expo '67 in Montreal, the Sun Life "carillon" rang electronic bells from La Tour de Lévis in Parc Hélèn de Champlain. The carillon rang the opening and closing of Expo every day with the exhibition's theme song, "Hey Friend, Say Friend," as well as the folk song "Un Canadien errant" and other music. ${ }^{4}$ The "carillon" used was designed by Schulmerich Carillons, a company whose "electro-mechanical" carillons emulated bells sounds with small pieces of metal amplified by loudspeakers; a photo published in a special "Expo edition" of Sun Life Review shows several of these large loudspeakers, clearly designed to look like bells, being lifted up the tower. Schulmerich also designed carillon for the 1964 World's Fair in New York, and for Expo 58 in Brussels. That a "carillon" not featuring cast bells caused some irritation to Canada's carillonists, even decades later, is clear from a 1992 pamphlet for the

3 Kimberly Schafer shows that many carillons were constructed on American university campuses during the same interwar period (2010, 92-96).

4 An LP of some selections performed by carillonneur Lucien Hétu was released in 1967 as both Au Carillon Sun Life du Centenaire (RCA-Victor, CGPS-248) and At the Sun Life Centenary Carillon (RCA Camden CAL-2153). 
Peace Tower carillon: "When listening to a carillon, one is hearing bells, not a recording of bells, and not synthesized bells. There is nothing electronic or even electrical in a carillon; some would say that it is an 'acoustic' instrument. If one is listening to loudspeakers in a tower, one is not hearing a carillon but a synthesizer, or perhaps a recording of a carillon. In either case, though, an attempt is being made to fool listeners into believing that they are hearing a carillon" (House of Commons Public Information Office 1992, 2).

The Sun Life carillon puts in relief the role of institutional privilege attached to a carillon ringing under the authority of a church, school, state-or financial institution, in the later twentieth century. ${ }^{5}$ In each case, the instrument has been a useful representation of embodied and sonified power, because the institution sponsoring the ring becomes understood as the authority underwriting the instrument, since both the bells and the performer are, as Luc Rombouts writes, "like God, largely invisible" $(2014,32)$.

We can perhaps register the importance of carillon as instruments of colonial peacetime and settler connection to the Crown through the titular essay of Mackenzie King's collected addresses, published in 1928, "The Message of the Carillon." Explaining how speeches and addresses were chosen for the volume, Mackenzie King writes in the preface, "I have been careful not to include speeches dealing with controversial politics. The message of the carillon is a message of peace and good-will. Some of its notes will, I believe, be found in each of the selections which go to make up the pages of this book" (Mackenzie King 1928, viii; my italics). Noise and dissent have no place in these writingsthe quotation recalls Tiffany Ng, who writes of the "idealistic misapprehension by politicians and diplomats of the nature of carillon bells, which are physically forced after casting into nearly identical spectral profiles via a destructive tuning process." That politicians take this "as democratic representations of different parties working in harmony" clearly underlines the fundamental fault of the political metaphor $(2015,142)$.

Mackenzie King extends the metaphor in a speech given that summer at the opening of the Canadian National Exhibition in Toronto (future cite of a carillon), where he knotted together in celebration the railway, radio, and the carillon in building a modern Canada:

For the first time in the history of Canada, the words spoken on Parliament Hill and the sound of its chimes and bells were carried instantaneously to, and heard simultaneously in, all parts of this vast dominion ... On ... July the first, all Canada became ... a single assemblage, swayed by a common emotion, within the sound of a single voice. Thus has modern science for the first time realized in the great nation state of modern days that condition which existed in the little city-states of ancient times, and which was considered by the wisdom of the ancients as indispensable to free and democratic government, namely, that all the citizens should be able to hear for themselves the living voice [of democracy] ... Henceforth,

5 Kimberly Schafer discusses the role of carillon on American university campuses as functioning alongside "pronouncements of the institution" rather than as a parallel to student-oriented musical activities like glee clubs and marching bands $(2010,89)$. 
all Canadians will stand with the sound of the carillon, and within hearing of the speakers of Parliament Hill. (Mackenzie King 1928, 79)

For Mackenzie King-as for many others who follow on this rhetorical trope of the carillon as harmonious - the carillon is the very sound and voice of democracy. Most importantly, the carillon, as carried around the country on radio broadcast (remember that to this point there were only a handful of instruments in Canada, all in southern Ontario), was articulated as fused with the human voices of representatives on Parliament Hill as a combined message that "served to stir the imagination of the people of our own and other lands." This applied to both those whom King calls "Native Canadians"-meaning already-settled Europeans, discussed further below-and recent immigrants, whom he calls "newcomers." For Mackenzie King, the carillon and radio could correct the wrong by which members of both groups hitherto turned their national consciousness toward "London, Paris, the Emerald Isles, or Washington." Instead, they could now turn towards and listen to Ottawa as symbolized in the harmonious ringing of the carillon bells that united the entire commonwealth. ${ }^{6}$

Mackenzie King's assertions, and the context of the peace carillons at Parliament Hill, Simcoe, Toronto, and Guelph are remarkable for several reasons. Any of the "native Canadians" King refers to-that is, those born in Canadahad no actual association with carillons other than as mythical symbols of the Old World, which, for the most part, they had only heard about-or, in the case of veterans like Nornabell, had perhaps encountered during service in the war. Nevertheless, within this context, in a Canada now sixty years oldidentical to but distinct from a land hundreds of years settled, and occupied since time immemorial-the carillon had no real history beyond the joined concepts of war, on the one hand, and nostalgia for Old World ideals of community, on the other. It could not be said ever to have represented any concrete idea of communal harmony within Canada. Mackenzie King's "Message of the Carillon" was little more than wishful thinking, a manifesto from the seat of power about the way things were going to go. Following Martin Puchner in his history of the manifesto, we could say that Mackenzie King was projecting and theorizing the subject that would help realize his vision, by constructing a symbol that could be referred to in asserting its existence (Puchner 2006, 29). The most important thing is that the causal connection between the harmony of the bells and the harmony of the community that might have allegorically held up as a political metaphor in the communes of France or the villages of the Netherlands-where bells were often cast and purchased through community conscription, with villagers even throwing in their own pieces of metal

6 The close tie articulated for the 1 July celebration between CN Rail, broadcast radio (not yet the $\mathrm{CBC}$ ), and the Parliament Hill carillon are made clear in a report from Canada National Railway Magazine, where C.J. Hanratty wrote, "The estimates run into the millions and even imagination is rather staggered by the suggestion that at least five million people were enabled to hear the sounds of the great carillon from the Victory Tower at Ottawa." Quoted in CBC Digital Archives (1927). 
at the time of casting (Corbin 1996, 86) 7 -had been inverted, or perhaps made atemporal. Rather than a political metaphor that represented a former way of life, the carillon was introduced as the symbol of a unity that was aspired to. ${ }^{8}$

Mackenzie King and his government aimed to construct this unity, and the carillon and its singular message of harmony played central ideological roles in concretizing this discourse in brick and brass. At best, this unifying message had to be imagined, and at worst it had to be forced. Mackenzie King's claims about the message of the carillon as one of unity for all Canadians has clearly not taken into account the First Nations peoples upon whose territories his imagined, harmonious Canada sat. During his time in office, the Indian residential school system played the role of imposition under the direction of Duncan Campbell Scott. Scott is most famously associated with a claim that he made in Parliament in 1920-the year Mackenzie King became Liberal leader and only months before he became prime minister-that the object of the Department of Indian Affairs was "to continue until there is not a single Indian in Canada that has not been absorbed into the body politic" (TRC 2016, 5). The message of the carillon, then, when imported into a colonized land that has always pretended it was not a colonized land, is one of forced, violent, and genocidal assimilation. The singular body politic that the bells of the carillon sound is a community projected into the future, one that combined Campbell's genocidal bureaucracy and Mackenzie King's carillon rhetoric to erase any individuals who were not part of the singular image of a future Canada. We should return here to Ng's more accurate political metaphor found in the production of carillon bells, "which are physically forced after casting into nearly identical spectral profiles via a destructive tuning process."

This force was undertaken primarily by the Indian residential school system-a system that, within the terms the Truth and Reconciliation Commission, stands as an attempted cultural genocide (TRC 2015b, 1). ${ }^{9}$ Andrew Woolford (2015) and Christopher Powell and Julia Peristerakis (2014, 72-74), among many others, have criticized this phrase, so common in the media imagination of the schools, as doubly faulted. First because claiming that Canada attempted genocide suggests a distancing, despite the fact that within the United Nations definition, attempted genocide is genocide; the extent to which violence and atrocities achieve their goal, and the resilience of the people upon whom it is attempted, are irrelevant to its legal definition. And second, because claiming that it is cultural implies merely cultural, it attempts to get Canada off the hook

7 Corbin notes cases in which those who failed to contribute to the construction of the bell were penalized for failing to help the cast bell represent the entire community (1996, 84 and 88).

8 More recently, we can perhaps here draw a parallel to the current discourse of "reconciliation" as criticized by David Garneau: "The word suggests that there was a time of general conciliation between First Nations, Inuit, and Métis people and Canada, and that this peace was tragically disrupted by Indian residential schools and will be painfully restored through the current process of Re-conciliation." See Garneau $(2016,30)$.

9 Indeed, the TRC literature is quite clear on distinguishing this cultural genocide from other forms; the first paragraph of the summary of the final report concludes, "The establishment and operation of residential schools were a central element of [Canada's Aboriginal] policy, which can best be described as 'cultural genocide"' (TRC 2015b, 1). 
by suggesting that it was not a physical or biological genocide. ${ }^{10}$ Nevertheless, prior to and during the years of Mackenzie King's administration, D.C. Scott and the Department of Indian Affairs streamlined and increased the reach of the residential schools many times over. In 1920, the Indian Act made attendance at the school mandatory for Indigenous youth; in 1930, the Act was altered to extend the compulsory age of attendance from fifteen up to sixteen; and in 1933, Royal Canadian Mounted Police officers were officially given the power of truancy officers. This is not the place for a full account of the history of residential schools; my primary goal here has been to choose a few prominent dates that coincide with Mackenzie King's government and are closely adjacent to his obsessive focus on the trinity of carillon, radio, and railway.

These institutional developments at the residential schools occurred under a system within which student-survivors frequently testified that they were "living by bells" (Miller 1996, 339). Beverley Diamond and Dylan Robinson have both turned their attention to bells as one element in a larger sonic regime of colonial order within the schools (Diamond 2011; Robinson 2019). Indeed, survivor testimonies even just in the official publications of the Truth and Reconciliation Commission frequently reveal the traumatic impact of what Diamond calls the "rigid organization of time that contrasted markedly with the context-sensitive way of life that Aboriginal children had come from" (2011, 131). "There seemed to be bells everywhere," one student testified. "There was the morning bell at seven ... then there was a bell for breakfast, one for classes at nine ... and others too" (TRC 2012, 23). Another student, reflecting on her time in the system, writes, "All around the schoolyard there were fences, beyond which we didn't set foot. Bells were ringing all day long" (23-24). Survivor Louise Moine recalls, "From the time we got out of bed at the sound of the bell, we went down on our knees to pray. After we had washed and dressed, we headed for the chapel to attend Low mass" (TRC 2015b, 73). In one TRC publication, within a subheading labelled "Maintaining Order," bells play a major role (TRC 2015a, 518-19). That students clearly understood the different tonal and semantic meanings implied in listening to each bell is made clear by a document from 1915 in which a student named Simon Gavin explains how the bells structured his morning chores: "When I hear the big bell I come in and brush my hair; when the little bell rings I line up with the other boys in the play-room and march in to school" (518). Another student named Gilbert Wuttunee, at a school in the late nineteenth century, remembers, "We were controlled altogether by the bell" (518). A larger passage comes from a 1939 history of the school in Chapleau, Ontario:

On week days the rising bell rings at six o'clock; at six-thirty another bell calls bigger girls to help with the work in the kitchen and dining-room, and the bigger boys to help with the work at the barn; at seven o'clock the bell is rung again to call all to breakfast, and at seven-thirty prayers are

10 Patrick Wolfe is similarly critical of the concept of what he calls "qualified" or "hyphenated" genocides, and instead suggests the term structural genocide for settler-colonial nations in which it is an ongoing process, or structure, rather than an event. See Wolfe (2006). 
conducted ... At eight forty-five the warning bell for classroom work is rung, and at nine o'clock all who have not been assigned to some special duties enter their respective classrooms. Bells are rung again at recess, at noon, and at various times in the afternoon, each ring having a definite meaning, well understood by all, until the final bells of the day are rung for evening study, choir practice, lights out, and go-to-bed. (TRC 2015a, 519)

This sonic and temporal organization aimed to break Indigenous children from their families, language, and culture such that students are sonically impelled to learn different relationships even to time. Students were expected to internalize the individual meaning of several rings per day and how that should dictate their relationship to time and their imposed duties and obligations. ${ }^{11}$ At the same time, settler Canadians were being trained into a form of nostalgic listening ${ }^{12}$ within which bells were a symbol of the harmonious community shared by both "native" and "newcomer" Canadians, with its reference to Old World community. This is precisely where Scott's imagined body politic meets Mackenzie King's message of the carillon.

In Canada, institutional bells-whether of the school, the church, or the state-served a dual instrumental function, both musical and colonial, in the interwar years. While in seventeenth-century Florence, the Amsterdam of Burney's visit in the eighteenth century, or a French commune in the nineteenth, bells marked the terms of always local dispute over their propriety, turning to Canada in the early twentieth century reveals a range of relationships to the sound of bells when considered in their national building role. There are first those like Mackenzie King, for whom, to quote $\mathrm{Ng}$ in another context, bells and carillon were "a sonic and visual symbol of nostalgia for an imaginary universal Old World heritage" $(2015,173)$. There are also the millions of Euro-settlers, "native" to Canada-meaning probably second or third generation-who had never heard a carillon until they tuned their radio to the Peace Tower broadcasts on Canada Day 1927. And there are lastly innumerable actual Natives, people actually indigenous to this land for whom bells were one more element in a newly colonized soundscape of violence, oppression, loss, trauma, and genocide.

11 Indeed, even in the nineteenth-century villages examined by Corbin, there is great animosity towards a bell that is not of the community. He quotes a letter from 1884 in which the town council of La Croix-aux-Mines rejected a bell placed in the courtyard by the priest: "We do not wish to have this foreign bell that does not belong to the commune, and whose shrill and irritating sound arouses discontent and universal and unanimous murmurings ... We can revert to our former ways and ring the bell that best suits us and is our property" $(1996,79)$.

12 Nostalgia is a theme long associated with bells. See most prominently Corbin (1998) and Schafer (2010) who thematize the issue. Corbin, for example, notes that "Napoleon loved the sound of bells above all else" (150) and recounts famous stories of him being stopped in his tracks by hearing bells in the distance and complaining that he could not hear the Angelus at Saint Helena from his prison on Elba, noting their importance for him as a reminder of his childhood hearing the bells at Saint-Cloud (291). Schafer similarly discusses the important role of bells as nostalgic for even university alumni donation campaigns $(2010,72)$. It is associations of this sort-childhood, school days, better times, etc.-that many Euro-American settlers associate with bells, in stark contrast to the foreign experience of children in residential schools. 


\section{REFERENCES}

Atkinson, Niall. 2016. The Noisy Renaissance: Sound, Architecture, and Florentine Urban Life. University Park: Pennsylvania State University Press.

Burney, Charles. [1772] 1969. The Present State of Music in Germany, the Netherlands, and United Provinces. New York: Broude Bros.

CBC Digital Archives. 1927. “1927: Diamond Jubilee Broadcast Links Canadians.” http://www.cbc.ca/archives/entry/1927-diamond-jubilee-broadcastlinks-canadians.

Corbin, Alain. 1998. Village Bells: Sound and Meaning in the Nineteenth-Century French Countryside. New York: Columbia University Press.

Diamond, Beverley. 2011. "Re'Thinking: Revitalization, Return, and Reconciliation in Contemporary Indigenous Express Culture." In The Trudeau Foundation Papers 3:121-40.

Garneau, David. 2016. "Imaginary Spaces of Conciliation and Reconciliation: Art, Curation and Healing." In Arts of Engagement: Taking Aesthetic Action In and Beyond the Truth and Reconciliation Commission of Canada, edited by Dylan Robinson and Keavy Martin, 21-42. Waterloo: Wilfrid Laurier University Press.

Granatstein, J.L. 2004. "William Lyon Mackenzie King (1874-1950).” Oxford Dictionary of National Biography.

House of Commons Public Information Office. Carillon, the Peace Tower, Houses of Parliament, Ottawa, Canada, 1992. Ottawa: Public Information Office, 1992.

Keyes, Sarah. 2009. “Like a Roaring Lion': The Overland Trail as a Sonic Conquest." Journal of American History 96 (1): 19-43.

Mackenzie King, Willam Lyon. 1928. The Message of the Carillon and Other Addresses. Toronto: MacMillan.

Miller, J.R. 1996. Shingwauk's Vision: A History of Native Residential Schools. Toronto: University of Toronto Press.

Ng, Tiffany. 2015. “The Heritage of the Future: Historical Keyboards, Technology and Modernism." PhD diss., University of California, Berkeley.

Nornabell, Henry Marshall. 1936. "An Address Given before the North American Congress of Carillonneurs." In The Layman and the Carillon. Lake Wales, FL: Highlander Publishing.

Powell, Christopher, and Julia Peristerakis. 2014. "Genocide in Canada: A Relational View." In Colonial Genocide in Indigenous North America, edited by Andrew Woolford, Jeff Benvenuto, and Alexander Laban Hinton, 70-92. Durham, NC: Duke University Press.

Puchner, Martin. 2006. Poetry of the Revolution: Marx, Manifestoes, and the Avant-Garde. Princeton: Princeton University Press.

Rancière, Jacques. 2006. Hatred of Democracy. New York: Verso.

Robinson, Dylan. 2019. Hungry Listening: Between Indigenous Ontologies of Song \& Settler Colonial Musical Logic. Minneapolis: University of Minnesota Press.

Rombouts, Luc. 2014. Singing Bronze: A History of Carillon Music. Leuven: Lipsius Leuven. 
Schafer, Kimberly. 2010. "Remembering and Performing the Ideal Campus: The Sound Cultures of Interwar American Universities." PhD diss., University of Texas at Austin.

Truth and Reconciliation Commission of Canada. 2012. They Came for the Children: Canada, Aboriginal Peoples, and Residential Schools. Winnipeg: TRC. - 2015a. Canada's Residential Schools: The History, Part 1: Origins to 1939. Montreal and Kingston: McGill-Queen's University Press.

- 2015b. Honouring the Truth, Reconciling for the Future: Summary of the Final Report of the Truth and Reconciliation Commission of Canada. Winnipeg: TRC.

- 2016. A Knock on the Door: The Essential History of Residential Schools from the Truth and Reconciliation Commission of Canada. Winnipeg: University of Manitoba Press.

Wolfe, Patrick. 2006. "Settler Colonialism and the Elimination of the Native." Journal of Genocide Research 8 (4): 387-409.

Woolford, Andrew. 2015. This Benevolent Experiment: Indigenous Boarding Schools, Genocide, and Redress in Canada and the United States. Lincoln: University of Nebraska Press.

\begin{abstract}
Bells and carillon have long symbolized the harmonious community in Euro-American political discourse. In this article, I denaturalize this rhetorical position by taking into account the context of bells and carillon in interwar Canada. I do so by reading William Lyon Mackenzie King's address at the inauguration of the Parliament Hill carillon within the broader context of Canada's colonial "Old World" nostalgia for the carillon. I then turn to testimony from survivors of the residential school system to argue that the link between bells, harmony, and community had to be forcefully imposed by settlers to banish any potential discord.
\end{abstract}

\title{
RÉSUMÉ
}

Les cloches et les carillons ont longtemps symbolisé l'harmonie de la communauté dans les discours politiques euro-américains. Cet article cherche à déconstruire cette posture rhétorique en reconsidérant les cloches et les carillons dans le contexte du Canada de l'entre-deux-guerres. Dans un premier temps, on y analyse le discours d'inauguration du carillon de la Colline Parlementaire de William Lyon Mackenzie King à travers le prisme d'une nostalgie canadienne coloniale propre à l'«ancien monde» pour le carillon. On analyse ensuite les témoignages de survivants du système canadien d'internats pour montrer que le lien entre les cloches, l'harmonie et la communauté a été fortement imposé par les colons afin d'éliminer à la source toute discorde potentielle. 


\section{BIOGRAPHY}

Patrick Nickleson is visiting assistant professor of music history at Mount Allison University. His work focuses on the politics of authorship and historiography, especially in experimental musics, and can be found in Twentieth Century Music, New Music Box, the American Musicological Society's "Musicology Now" blog, and forthcoming in The University of Toronto Quarterly. Nickleson is also closely engaged in the work of the philosopher Jacques Rancière and is the co-editor of Rancière and Music, forthcoming from Edinburgh University Press. 